\title{
Relationship Between Aluminum-Rich/Intermetallic Phases and Microhardness of a Horizontally Solidified AISiMgFe Alloy
}

\author{
Carolina Rizziolli Barbosa $a^{a}$,José Otávio Monteiro de Lima ${ }^{a}$, Gabriel Mendes Hirayama Machado, \\ Hugo André Magalhães de Azevedo ${ }^{a}$ Fernando Sousa Rocha ${ }^{a}$, André Santos Barros ${ }^{b}$, \\ Otávio Fernandes Lima da Rocha ${ }^{a, b} *$ (D) \\ anstituto Federal de Educação, Ciência e Teccnologia do Pará - IFPA, 66093-020, Belém, PA, Brasil \\ ${ }^{b}$ Faculdade de Engenharia Mecânica, Universidade Federal do Pará - UFPA, 66075-110, Belém, PA, \\ Brasil
}

Received: May 23, 2018; Revised: September 02, 2018; Accepted: October 03, 2018

\begin{abstract}
An experimental study with an A356-A1SiMgFe alloy was developed to evaluate the microhardness performance in the microstructure resulting of an unsteady-state horizontal solidification process. The Al-7wt $\% \mathrm{Si}-0.3 \mathrm{wt} \% \mathrm{Mg}-0.15 \mathrm{wt} \% \mathrm{Fe}$ alloy was elaborated and directionally solidified in a water-cooled horizontal solidification device. In order to experimentally determine the cooling and growth rates $\left(\mathrm{V}_{\mathrm{L}}\right.$ and $T_{R}$, respectively), a thermal analysis was also conducted during solidification. Microstructural characterization by optical microscopy, SEM/EDS elemental mapping and microanalysis of the punctual EDS compositions allowed to observe the presence of an Al-rich dendritic phase $\left(\mathrm{Al}_{(\alpha)}\right)$ with interdendritic phases second composed of an eutectic mixture: $\mathrm{Al}_{(\alpha \text {-eutectic })}+\mathrm{Si}+\mathrm{Al}_{8} \mathrm{Mg}_{3} \mathrm{FeSi}_{6(\pi)}$ $+\mathrm{Mg}_{2} \mathrm{Si}_{(\theta)}$. Furthermore, the dendritic microstructure was characterized by measuring the secondary dendritic spacings $\left(\lambda_{2}\right)$ along the horizontally solidified ingot. Higher HV values were observed within the eutectic mixture.
\end{abstract}

Keywords: Solidification process, Unsteady-state heatflow, Intermetallic phases, Microhardness, AlSiMg alloys.

\section{Introduction}

It is known that aluminum-based multicomponent alloys due to their high strength/weight ratio have been considered as one of the most promising materials for application in the automotive and aerospace industries as well as in those referring to electrical and naval engineering ${ }^{1-32}$. Depending on the product, these alloys can be classified as plastic deformation and/or casting alloys. Among these alloys, especially those for casting, are highlighted those containing silicon as the main alloying element. In Al-Si alloys, the addition of some alloying elements $(\mathrm{Mg}$ and $\mathrm{Cu}$, as example) increases the strength by solid solution or precipitation hardening ${ }^{32}$. This hardening occurs through the formation of barriers that hinder the movement of dislocations. It is highlighted that the Al-(5 to 12$) \mathrm{wt} \% \mathrm{Si}$ casting alloys with addition of magnesium ranging from 0.2 to $0.5 \mathrm{wt} \%$ allows the hardening of the matrix by precipitation of second phases, with emphasis to the $\mathrm{Mg}_{2} \mathrm{Si}$ phase, after solution and artificial aging heat treatments ${ }^{29-32}$.

It is important to emphasize that the mechanical properties of as-cast products depend on grain size, dendritic, lamellar or fibrous spacing, heterogeneities of chemical composition, size, shape and distribution of inclusions, formed porosity, etc., whose characteristics are controlled and improved by refining the microstructure ${ }^{11-16}$. It is known that the dendritic morphology is the microstructure predominantly observed in castings, whose characterization consists of the quantification of a structural parameter known as interdendritic spacing, which is obtained by measuring of the primary $\left(\lambda_{1}\right)$, secondary $\left(\lambda_{2}\right)$ and tertiary $\left(\lambda_{3}\right)$ dendrite arm spacings. These parameters are used to determine the effects of the solidification conditions, notably by the thermal parameters among which the growth rate $\left(\mathrm{V}_{\mathrm{L}}\right)$ and cooling rate $\left(\mathrm{T}_{\mathrm{R}}\right)$. It is a consensus from the works reported in the literature ${ }^{2-6,8-}$ ${ }^{40}$ that the mathematical expressions that characterize the dependence of the dendritic spacings with the solidification thermal parameters are described by the following general formula $\lambda_{123}=$ Constant. $\left(\mathrm{V}_{\mathrm{L}}, \mathrm{T}_{\mathrm{R}}\right)^{\mathrm{a}}$, where the constant and exponent values depend on the types of alloys and the growth direction (vertical/horizontal) of the solidification process. In the case of unsteady-state directionally solidified binary alloys, both theoretical and experimental mathematical equations that correlate $\lambda_{2}$ as a function of $V_{L}$ and $T_{R}$, the proposed exponents are $-2 / 3$ and $-1 / 3$, respectively. It is highlighted the mathematical model of Bouchard-Kirkaldy ${ }^{16}$ that predicts the growth of $\lambda_{2}$ as a function of $\mathrm{V}_{\mathrm{L}}$ is given by $\lambda_{2} \alpha \mathrm{V}_{\mathrm{L}}^{-2 / 3}$, whose exponent $(-2 / 3)$ has been validated by several experimental investigations on unsteady-state directional solidification of aluminum-based binary and multicomponent alloys, for both horizontal and vertical directions ${ }^{2,16,17,23,25-28,38,39}$. Among the works on transient solidification, it is emphasized those 
reported for binary $\mathrm{Al}-\mathrm{Si}^{2,38,39}$ and multicomponent $\mathrm{Al}-\mathrm{Si}-(\mathrm{Cu}$ and $\mathrm{Mg})^{23,25-28,30}$ alloys.

With regard to the investigations on upward steadystate solidification, Kaya et al. ${ }^{5,6}$ and Çadirli ${ }^{41}$ have reported different exponents values for binary Al-Si and Al-Cu alloys, respectively. The following mathematical relations given by $\lambda_{2} \alpha \mathrm{V}_{\mathrm{L}}^{-0.47}$ and $\lambda_{2} \alpha \mathrm{V}_{\mathrm{L}}^{-(0.27 \text { to } 0.46)}$ have been proposed by Kaya et al. ${ }^{6}$ for Al-3wt $\%$ Si and Çadirli ${ }^{41}$ alloys for Al-XCu $(\mathrm{X}=3,6,15,34$ and $33 \mathrm{wt} . \% \mathrm{Cu})$ alloys, respectively. For multicomponent alloys, Rappaz-Boettinger ${ }^{22}$ have reported a mathematical model that correlates $\lambda_{2}$ with a function of the local solidification time $\left(\mathrm{t}_{\mathrm{SL}}\right)$ given by the general formula $\lambda_{2}=5.5$. $\left[\mathrm{M}\left(\mathrm{t}_{\mathrm{SL}}\right)\right]^{1 / 3}$, which has been validated by works elaborated by the own authors ${ }^{22}$ and, more recently, by our investigations with horizontally solidified Al-Si-Cu alloys ${ }^{25,27,28}$.

Although the literature has presented in the last decades a large number of studies on the structural evolution of casting alloys, due to the number of operational and thermal parameters involved during the solidification, several aspects of physical nature related to the formation of the macrostructure and microstructure of products obtained by casting still need to be effectively understood, especially with respect to the solidification growth direction and, consequently, the effect of the gravity that acts during the process. It is evidenced from the literature that most studies on directional solidification consider the upward direction, where the direction of the gravity is parallel to that of heat extraction, but contrary to the advance of solidification, promoting better thermal stability to the process ${ }^{2,5,6,8,9,17,18,23,25-27,31,36}$. On the other hand, in horizontal solidification, the gravity is perpendicular to

THERMO.CALC (2017.10.06:16.03) : DATABASE:TTAL5

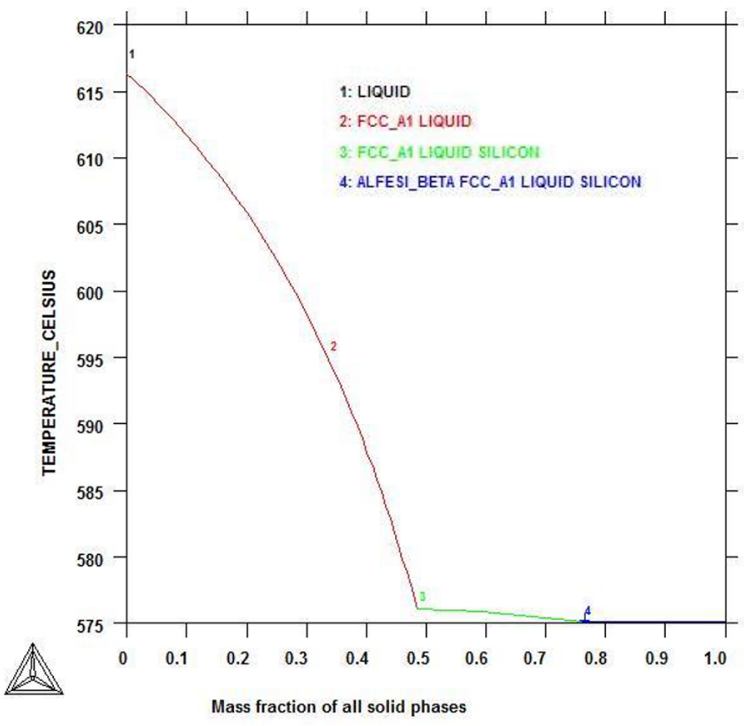

(a) the heat flow and solidification advance direction and, in this case, thermal instabilities are always present due to the effects of thermal and solutal convections $s^{3,4,21,25,28,37}$. In a recent study ${ }^{25}$, the $\mathrm{Al}-4 \mathrm{wt} \% \mathrm{Si}-6 \mathrm{wt} \% \mathrm{Si}$ alloy was solidified upwards and horizontally and the effect of the gravity has been discussed, where microanalyses by EDS compositons have shown that the dendritic microstructure is more refined, and that the results of the microssegration demonstrated that in upward solidification the $\mathrm{Si}$ is more confined between the interdendritic branches reducing the $\lambda_{1}$ and $\lambda_{2}$ values.

The composition of Al-Si alloys is determined by the amount of iron impurity present. It is emphasized that iron (Fe) levels generally vary from $0.04 \%$ (best primary metal) to $0.50 \%$ (secondary metal), with typical primary levels in the 0.1 to $0.2 \%$ range $^{30,32}$. In this sense, the formation of $\mathrm{Fe}$-intermetallic phases during the solidification of $\mathrm{Al}-\mathrm{Si}$ alloys is inevitable, as can be seen by the solidification paths of $\mathrm{Al} 7 \mathrm{Si} 0.15 \mathrm{Fe}$ and $\mathrm{Al} 7 \mathrm{Si} 0.3 \mathrm{Mg} 0.15 \mathrm{Fe}$ alloys shown in Figure 1. It is observed that for Al-Si hypoeutectic alloys (Figure 1a) the microstructure is predicted to consist of a primary phase $\left(\mathrm{Al}_{\alpha}\right)$ and by an eutectic mixture $\mathrm{Al}_{(\alpha-\text {-eutectic) }}+$ $\mathrm{Si}+\mathrm{Fe}$ intermetallic located between the $\mathrm{Al}_{\alpha}$ phases. On the other hand, the theoretical prediction of the microstructure for the alloy for the $\mathrm{Al} 7 \mathrm{Si} 0.3 \mathrm{Mg} 0.15 \mathrm{Fe}$ alloy consists of a $\mathrm{Al}$-rich primary phase $\left(\mathrm{Al}_{(\alpha)}\right)$ and an eutectic mixture resulting from complex transformations of secondary phases, containing the eutectic phase $\mathrm{Al}_{(\alpha)}$ and intermetallic compounds, i.e: $\mathrm{Al}_{\text {(a-eutectic) }}+\mathrm{Si}+\mathrm{Al}_{8} \mathrm{Mg}_{3} \mathrm{FeSi}_{6}(\pi)+\mathrm{Mg}_{2} \mathrm{Si}(\theta)+\mathrm{Fe}$ intermetallic. Figure 2 shows, for the $\mathrm{Al} 7 \mathrm{Si} 0.3 \mathrm{Mg} 0.15 \mathrm{Fe}$ alloy, a prediction illustration of the microstructural evolution

THERMO-CALC (2017.02.16:16.56) : DATABASE:TTAL7

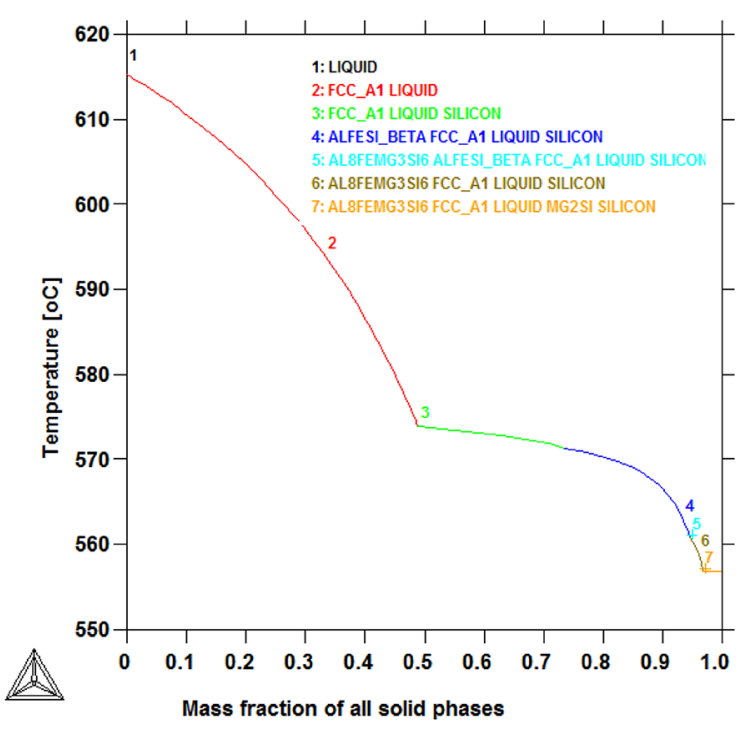

(b)

Figure 1. Solidification paths for Al-7Si- $(0.3 \mathrm{Mg} ; 0.15 \mathrm{Fe})$ alloys obtained by Thermo-Calc. 


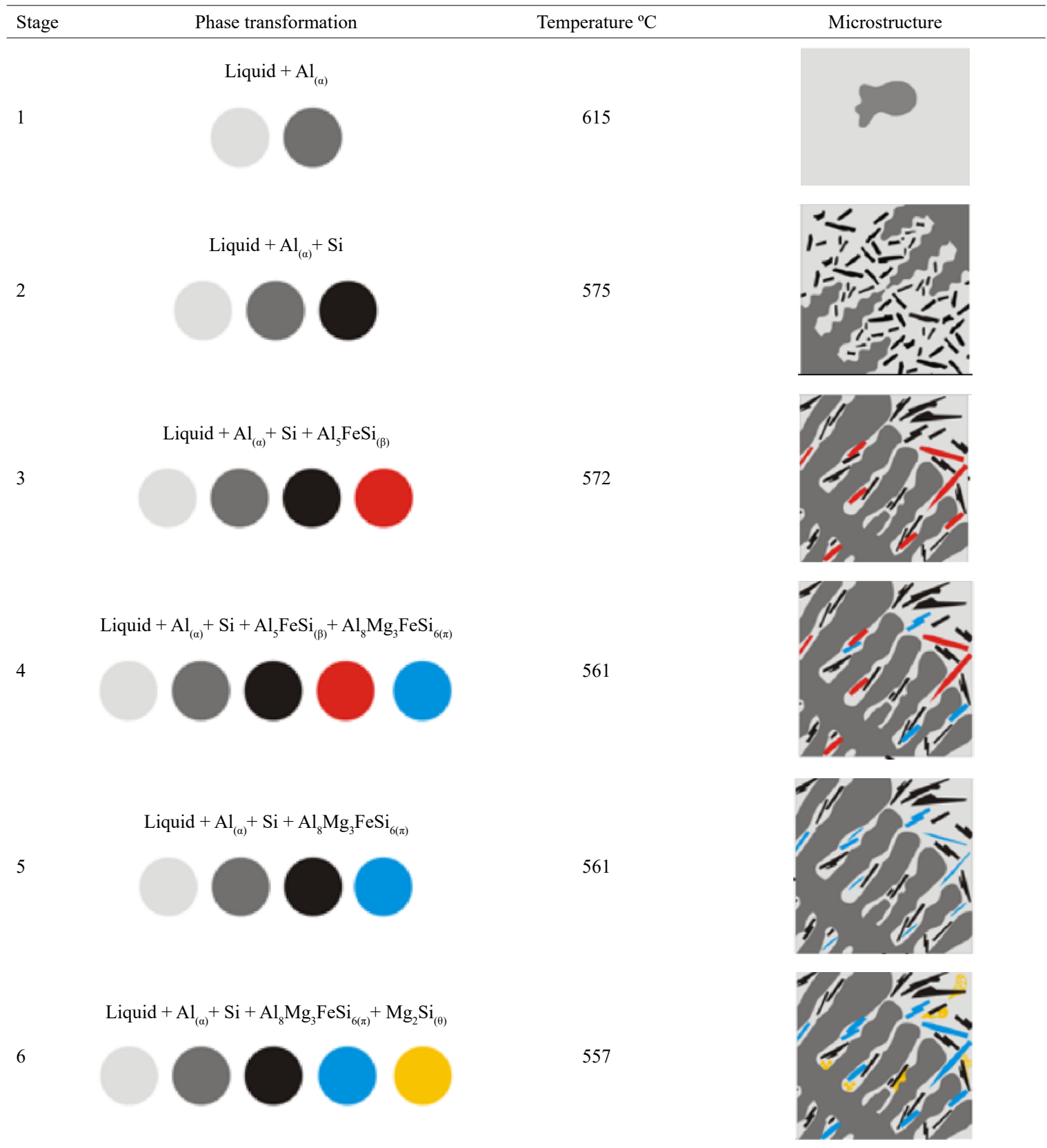

Figure 2. Schematic of complex phase transformations during the solidification of Al- $7 \mathrm{wt} \% \mathrm{Si}-0.3 \mathrm{wt} \% \mathrm{Mg}-0.15 \mathrm{wt} \% \mathrm{Fe}$ alloy.

with the respective formation start temperatures of each phase shown by the solidification path (Figure 1b).

The dependence of the microhardness (HV) on the microstructure in Al-based binary and multicomponent alloys has been investigated for several directional solidification systems $s^{23,28,38,41-48}$ and the results obtained in these studies have shown that power and Hall-Petch types experimental equations may characterize the variation of $\mathrm{HV}$ with $\lambda_{1}, \lambda_{2}$ and $\lambda_{3}$, of which the alloys containing the Si as the major alloying element with $\mathrm{Cu} / \mathrm{Mg} / \mathrm{Sn}$ addition are highlighted. This can be seen in Table 1 .
Chen et al. ${ }^{30}$ have proposed a study on the interconnection between solidification microstructures with $\mathrm{T} 6$ heat treatment, whose results showed that more refined dendritic microstructures, i.e., smaller secondary dendritic spacings inherited greater yield strength $\left(\sigma_{\mathrm{YS}}\right)$ and ultimate tensile strength $\left(\sigma_{\mathrm{UTS}}\right)$ after heat treatment. These authors have proposed to the literature for the as-cast $\mathrm{Al}-7 \mathrm{wt} \% \mathrm{Si}-0.3 \mathrm{wt} \% \mathrm{Mg}$ alloy the following mathematical equations: $\sigma_{\mathrm{YS}}=0.0041\left(\lambda_{2}\right)^{2}+0.118\left(\lambda_{2}\right)+111.1$ and $\sigma_{\text {UTS }}=0.029\left(\lambda_{2}\right)^{2}+1.72\left(\lambda_{2}\right)+155.8$.

In Al-Si cast alloys the Si particles have a plate (or lamellar) type morphology, which acts as initiators for crack propagation and has a negative influence on ductility. 
This can be improved by changing the morphology of the Si from lamellar to fibrous or spheroidal, imposing, for example, high cooling rates $\left(\mathrm{T}_{\mathrm{R}}\right)$ during solidification, or by the addition of a chemical modifier or by heat treatment, or by a combination of such processes. The microstructural characteristics and properties corresponded presented by the multicomponent $\mathrm{Al}-7 \mathrm{wt} \% \mathrm{Si}-0.3 \mathrm{wt} \% \mathrm{Mg}-0.15 \mathrm{wt} \% \mathrm{Fe}$ alloy, very well designed during the solidification and heat treatment processes, allow it to be one of the most applied aluminum-based nonferrous metal alloys in the aerospace and automotive industries $\mathrm{s}^{30,32}$.

As can be seen from Table 1, HV dependence on the microstructure has been evaluated as a function of the dendritic spacing values, however, there is still a gap in the literature about a study of the effects on microhardness of primary and secondary phases that are form during the solidification path of Al-based ternary alloys, in particular on horizontal solidification of AlSiMgFe alloys. Thus, the goal of this paper is to analyze the relationship between aluminum-rich/ intermetallic phases and microhardness of the horizontally solidified Al-7wt.\%Si-0.3wt.\%Mg-(0.15wt.\%Fe) alloy. In addition, the microstructural evolution in aluminum alloys has been evaluated in the majority for binary alloys and, in this sense, there is still a great vacancy in the literature on studies of directional solidification, especially in the horizontal direction.

\section{Experimental Procedure}

The Al-7wt $\%-$ Si-0.3wt $\% \mathrm{Mg}-0.15 w t \% \mathrm{Fe}$ alloy was elaborated and directionally solidified in a water-cooled horizontal solidification device. Figure 3 shows a schematic of the device used to perform the horizontal solidification of the investigated alloy. It has been detailed and recently published ${ }^{28}$ and it was designed for the heat extraction process to be conducted only by a cooled mold plate, located on one of the sides of a stainless steel rectangular mold, which has the following dimensions: thickness of $3 \mathrm{~mm}$, a length of

Table 1. HV dependence on $\lambda 1, \lambda 2$ and $\lambda 3$ reported in the literature for Al-based alloys.

\begin{tabular}{|c|c|c|c|c|}
\hline solidification systems & Authors & Alloys & \multicolumn{2}{|c|}{$\begin{array}{l}\text { Experimental equations }\left(\mathrm{HV}\left[\mathrm{kgf} / \mathrm{mm}^{2}\right] \mathrm{e}\right. \\
\left.\qquad \lambda_{2}[\mu \mathrm{m}]\right)\end{array}$} \\
\hline \multirow{8}{*}{ Steady-state upward } & \multirow{3}{*}{ Kaya et al. ${ }^{42}$} & Al-3wt. $\% \mathrm{Cu}$ & $\mathrm{HV}=525.23\left(\lambda_{1}\right)^{-0.4}$ & $\mathrm{HV}=141.55\left(\lambda_{2}\right)^{-0.30}$ \\
\hline & & Al-3wt. $\% \mathrm{Si}$ & $\mathrm{HV}=198.14\left(\lambda_{1}\right)^{-0.28}$ & $\mathrm{HV}=96,83\left(\lambda_{2}\right)^{-0.25}$ \\
\hline & & Al-1wt.\%Ti & $\mathrm{HV}=472.06\left(\lambda_{1}\right)^{-0.43}$ & $\mathrm{HV}=179.85\left(\lambda_{2}\right)^{-0.32}$ \\
\hline & \multirow{4}{*}{ Çadirli $^{41}$} & Al-3wt. $\% \mathrm{Cu}$ & $\mathrm{HV}=307,64\left(\lambda_{1}\right)^{-0.29}$ & $\mathrm{HV}=121.15\left(\lambda_{2}\right)^{-0,21}$ \\
\hline & & Al- $6 w t . \% C u$ & $\mathrm{HV}=344,31\left(\lambda_{1}\right)^{-0.23}$ & $\mathrm{HV}=177.95\left(\lambda_{2}\right)^{-0.20}$ \\
\hline & & Al- $15 w t . \% C u$ & $\mathrm{HV}=685,49\left(\lambda_{1}\right)^{-0.25}$ & $H V=219.72\left(\lambda_{2}\right)^{-0.17}$ \\
\hline & & Al-24wt. $\% \mathrm{Cu}$ & $\mathrm{HV}=810,90\left(\lambda_{1}\right)^{-0.25}$ & $\mathrm{HV}=317.61\left(\lambda_{2}\right)^{-0.18}$ \\
\hline & Acer et al. ${ }^{43}$ & Al-5.5wt. $\% \mathrm{Zn}-2.5 w t . \% \mathrm{Mg}$ & $\mathrm{HV}=289\left(\lambda_{1}\right)^{-0.28}$ & $\mathrm{HV}=170\left(\lambda_{2}\right)^{-0.27}$ \\
\hline \multirow{9}{*}{ Unsteady-state upward } & Brito et al. ${ }^{23}$ & A-3wt. $\% \mathrm{Mg}$ & \multicolumn{2}{|c|}{$\mathrm{HV}=91-94.6\left(\lambda_{2}\right)^{-1 / 2}$} \\
\hline & \multirow{3}{*}{ Silva et al. ${ }^{44}$} & A-3wt. $\% \mathrm{Mg}-1$ wt. $\% \mathrm{Si}$ & \multicolumn{2}{|c|}{$\mathrm{HV}=17+415\left(\lambda_{2}\right)^{-1 / 2}-1350\left(\lambda_{2}\right)$} \\
\hline & & Al-1wt.\%Ni & \multicolumn{2}{|c|}{$\mathrm{HV}=21+94.1\left(\lambda_{1}\right)^{-1 / 2}$} \\
\hline & & Al-5wt.\%Ni & \multicolumn{2}{|c|}{$\mathrm{HV}=45+52\left(\lambda_{1}\right)^{-1 / 2}$} \\
\hline & Canté et al. ${ }^{45}$ & Al-1wt.\%Fe-1wt.\%Ni & \multicolumn{2}{|c|}{$\mathrm{HV}=21.5+59.5\left(\lambda_{1}\right)^{-1 / 2}$} \\
\hline & & Al-10wt. $\%$ Sn-10wt. $\% \mathrm{Cu}$ & \multicolumn{2}{|c|}{$\mathrm{HV}=67+84\left(\lambda_{1}\right)^{-1 / 2}$} \\
\hline & Berte & Al-20wt. $\%$ Sn-10wt. $\% \mathrm{Cu}$ & \multicolumn{2}{|c|}{$\mathrm{HV}=52+411.7\left(\lambda_{1}\right)^{-1 / 2}+84\left(\lambda_{1}\right)$} \\
\hline & Berteml et al. & Al-15wt.\%Sn-5wt.\%Si & \multicolumn{2}{|c|}{$\mathrm{HV}=38+45\left(\lambda_{1}\right)^{-1 / 2}$} \\
\hline & & Al-25wt.\%Sn-5wt.\%Si & \multicolumn{2}{|c|}{$\mathrm{HV}=32+89\left(\lambda_{1}\right)^{-1 / 2}$} \\
\hline \multirow{10}{*}{$\begin{array}{l}\text { Unsteady-state } \\
\text { Horizontal }\end{array}$} & Vasconcelos et al. ${ }^{47}$ & Al-5.5wt. $\% \mathrm{Sn}$ & $\mathrm{HV}=8.2\left(\lambda_{1}\right)^{0,3}$ & $\mathrm{HV}=37-1593.6\left(\lambda_{1}\right)^{-1 / 2}$ \\
\hline & Vasconcelos et al 48 & Al- $6 w t . \% C u$ & \multicolumn{2}{|c|}{$\mathrm{HV}=204\left(\lambda_{1}\right)^{-0.15}$} \\
\hline & & Al-6wt. $\% \mathrm{Cu}-8 w \mathrm{wt} . \% \mathrm{Si}$ & \multicolumn{2}{|c|}{$\mathrm{HV}=3926\left(\lambda_{1}\right)^{-0.6}$} \\
\hline & Barros et al..$^{21}$ & Al-3wt. $\% \mathrm{Cu}$ & \multicolumn{2}{|c|}{$\mathrm{HV}=47+147\left(\lambda_{1}\right)^{-1 / 2}$} \\
\hline & & Al-8wt. $\% \mathrm{Cu}$ & \multicolumn{2}{|c|}{$\mathrm{HV}=60+270\left(\lambda_{1}\right)^{-1 / 2}$} \\
\hline & Carvalho et al. ${ }^{38}$ & Al-9wt.\%Si & $\mathrm{HV}=97\left(\lambda_{2}\right)^{-0.25}$ & $\mathrm{HV}=41+67\left(\lambda_{2}\right)^{-1 / 2}$ \\
\hline & \multirow[t]{2}{*}{ Araújo et al. ${ }^{28}$} & $\mathrm{Al}-5.5 \mathrm{wt} \% \mathrm{Si}-3 \mathrm{wt} \% \mathrm{Cu}$ & $\mathrm{HV}=18\left(\lambda_{2}\right)^{-0.17}$ & $\mathrm{HV}=61+183\left(\lambda_{2}\right)^{-1 / 2}$ \\
\hline & & $\mathrm{Al}-3 \mathrm{wt} \% \mathrm{Cu}$ & $\mathrm{HV}=18\left(\lambda_{2}\right)^{-0.15}$ & $\mathrm{HV}=41+82\left(\lambda_{2}\right)^{-1 / 2}$ \\
\hline & \multirow[t]{2}{*}{ Souza et al. ${ }^{40}$} & Al-7wt. $\%$ Si-0.15wt. $\% \mathrm{Fe}$ & \multicolumn{2}{|c|}{$\mathrm{HV}=80-229\left(\lambda_{3}\right)^{-1 / 2}$} \\
\hline & & $\begin{array}{c}\text { Al-7wt.\%Si-0.15wt.\%Fe- } \\
\text { (3wt.\%Cu; } 0.3 \text { wt.\%Mg) }\end{array}$ & \multicolumn{2}{|c|}{$\mathrm{HV}=70$} \\
\hline
\end{tabular}




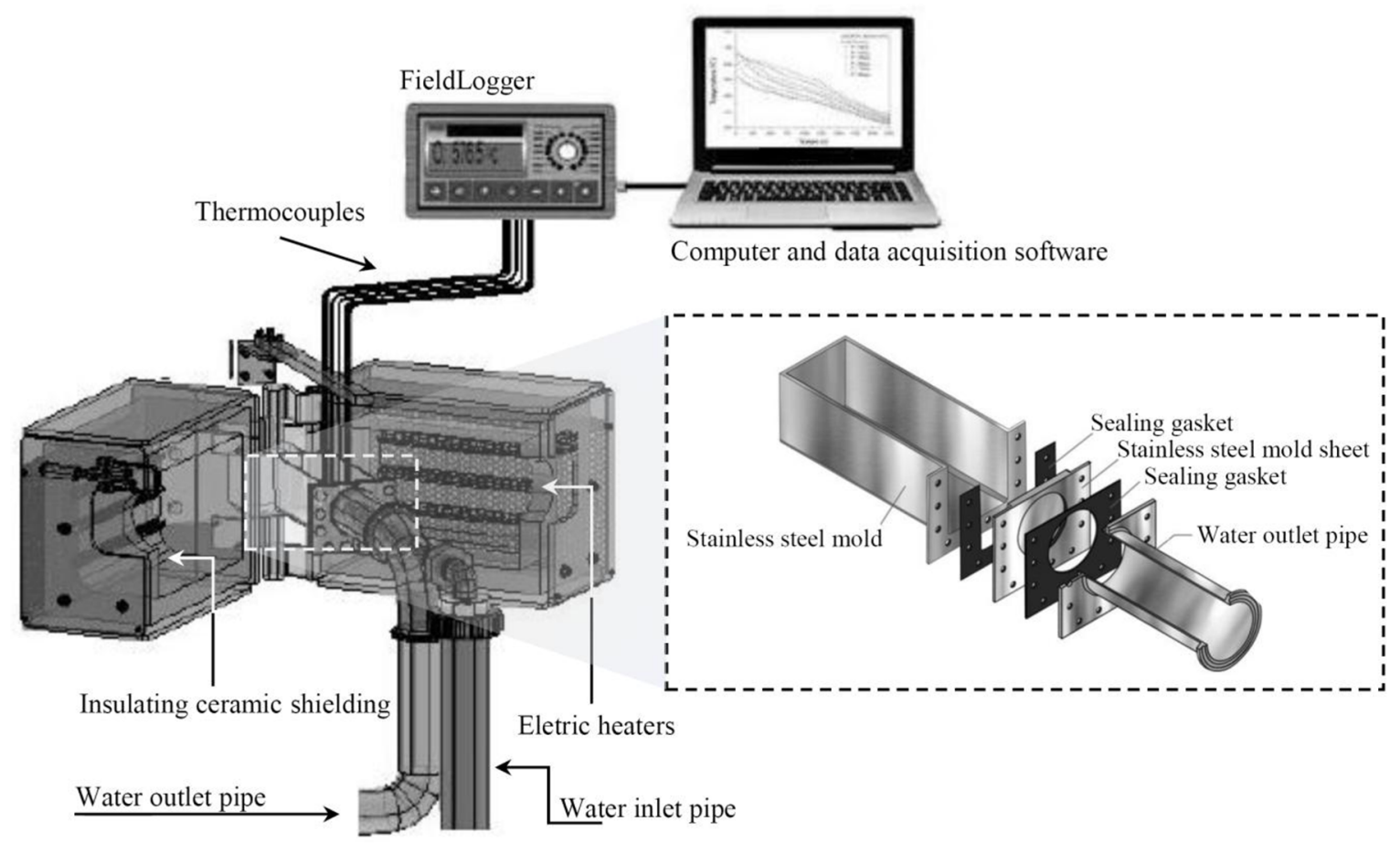

Figure 3. Scheme of the horizontal solidification apparatus used in this investigation.

$150 \mathrm{~mm}$, a height of $60 \mathrm{~mm}$, and a width of $60 \mathrm{~mm}$. It can be noted in Figure 3, within the dashed line area.

A thermal mapping was performed during the solidification process by a set of six thermocouples inserted in the liquid metal, which were positioned from the cooled mold. Figure 4 shows the cooling curves obtained, for each thermocouple, which were used to determine experimentally the solidification kinetic. It has been represented by a powertype mathematical expression given by $\mathrm{P}=$ Constant. $(\mathrm{t})^{\mathrm{n}}$, where " $\mathrm{P}$ " is the liquidus isotherm displacement and " $\mathrm{t}$ " is the time corresponding to the passage of this isotherm for each thermocouple, and the derivative of this equation allowed to obtain the growth rate $\left(\mathrm{V}_{\mathrm{L}}\right)$, i.e., $\mathrm{V}_{\mathrm{L}}=\mathrm{d}\left[\right.$ Constant. $\left.(\mathrm{t})^{\mathrm{n}}\right] / \mathrm{dt}$. The cooling rate has been determined by the derivative of each curve $[T=f(t)]$ obtained experimentally, i.e., $T_{R}=d T / d t$ for " $\mathrm{t}$ " equal to the time of passage of the liquidus isotherm for each thermocouple. This methodology has been detailed in several of our articles s,4,21,25-28. $^{3}$.

In order to reveal the macrostructure and microstructure, the resulting ingot was subjected to traditional metallography techniques, i.e, it was mechanically polished with abrasive papers and subsequently etched with a solution $70 \mathrm{ml}$ of $\mathrm{H}_{2} \mathrm{O}, 10 \mathrm{ml}$ of $\mathrm{HCl}, 15 \mathrm{ml}$ of $\mathrm{HNO}_{3}$ and $5 \mathrm{ml}$ of $\mathrm{HF} \sim 30 \mathrm{~s}$ for macrograph examination, and selected longitudinal (parallel to the growth direction) sections of the directionally solidified samples at $6,10,15,20,30,50,80$ and $100 \mathrm{~mm}$ from the cooled interface were electropolished and etched with an solution of $5 \%$ of $\mathrm{NaOH}$ in water $\sim 10$ s for micrograph examination. It was carried out to characterize and quantify the secondary dendrite arm spacing $\left(\lambda_{2}\right)$.

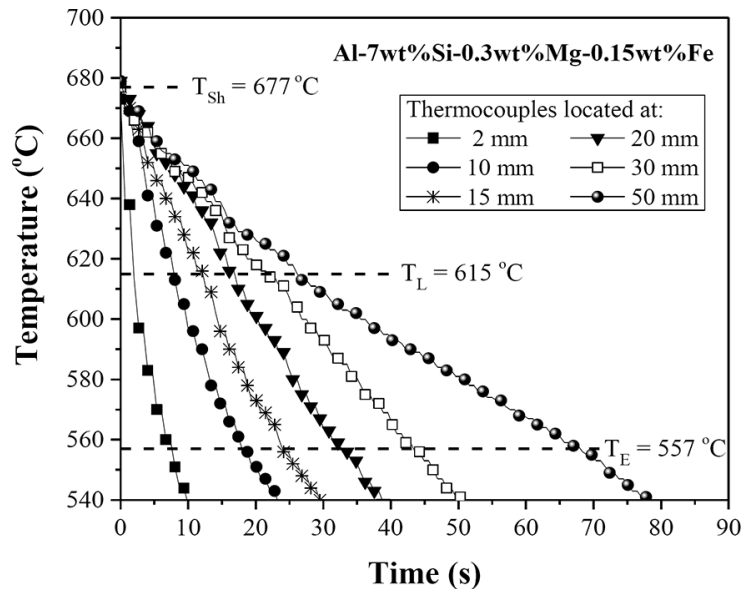

Figure 4. Experimental cooling curves for six positions of the horizontally solidified $\mathrm{Al}-7 \mathrm{wt} \% \mathrm{Si}-0.3 \mathrm{wt} \% \mathrm{Mg}$ alloy. $\mathrm{T}_{\mathrm{Sh}}, \mathrm{T}_{\mathrm{L}}$ and $\mathrm{T}_{\mathrm{E}}$, are the superheat, liquidus and eutectic temperatures of the studied alloy.

The mechanical strength of the studied alloy was evaluated by microhardness measurement. It has been carried out in the center of the dendrite, aluminum-rich phase, as well as in the eutectic mixture located in the interdendritic region of the $\mathrm{Al}-7 \mathrm{wt} \% \mathrm{Si}-0.3 \mathrm{wt} \% \mathrm{Mg}-0.15 \mathrm{wt} \% \mathrm{Fe}$ alloy. Figure 5 shows a representative scheme of the methodology used in this work to obtain the $\lambda_{2}$ and $H V$ values. It is emphasized that at least 10 and 20 measurements were obtained for HV (in each region) and $\lambda_{2}$, respectively. In the case of microhardness the quantity of measurements occurred in several points of interdendritic regions. 


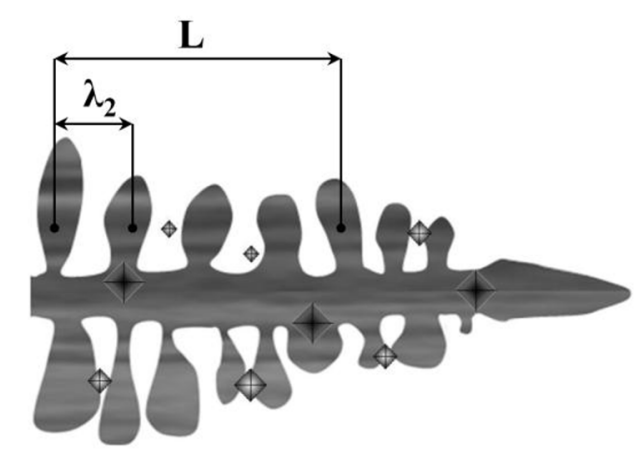

Figure 5. Measurement technique of the $\left(_{2}\right.$ and $\mathrm{HV}$ values.

A scanning electron microscope (SEM TESCAM, VEGA LMU) coupled to an energy dispersion spectrum (EDS X-MAX 20, Oxford) was used during microstructural characterization, and the microhardness measurements were carried out using by Shimadzu HMV-2 model hardness measuring test device using a $50 \mathrm{~g}$ load and a dwell time of 10 seconds.

\section{Results and Discussions}

Figure 6a shows the revealed macrography of the ingot of the investigated alloy and the microstructural evolution with the growth of the horizontal solidification. The dendritic morphology has been characterized along the length of the ingot as the microstructure of the primary phase $\left(\mathrm{Al}_{\alpha}\right)$. The dendritic $\mathrm{Al}_{\alpha}$ microstructure has been characterized by secondary dendritic spacing, and the $\lambda_{2}$ dependence on $\mathrm{V}_{\mathrm{L}}$ and $T_{R}$ values has been evaluated by power-type mathematical expressions given by the general formulas $\lambda_{2}=$ Constant. $\left(\mathrm{V}_{\mathrm{L}}\right)^{-2 / 3}$ e $\lambda_{2}=$ Constant. $\left(\mathrm{T}_{\mathrm{R}}\right)^{-1 / 3}$, as shown in Figure $6 \mathrm{~b}$. The values of the exponents of $-2 / 3$ and $-1 / 3$ are exactly equal to the values proposed by the Bouchard-Kirkaldy ${ }^{16}$ and Rappaz-Boettinger ${ }^{22}$ mathematical models, which characterize the $\lambda_{2}$ variation with the growth rate and local solidification time $\left(\mathrm{t}_{\mathrm{SL}}\right)$ through the following mathematical relations $\lambda_{2} \alpha \mathrm{V}_{\mathrm{L}}^{-2 / 3}$ and $\lambda_{2} \alpha \mathrm{t}_{\mathrm{SL}}{ }^{1 / 3}$, respectively. It is known that the local solidification time is the time corresponding to the passage of the solidus and liquidus isotherms $\left(\mathrm{T}_{\mathrm{E}}\right.$ and $\mathrm{T}_{\mathrm{L}}$ shown in Figure 4, respectively) by a certain position in the casting ${ }^{25}$, and the $\mathrm{t}_{\mathrm{SL}}$ has been reported in the literature ${ }^{7,25-28}$ to be determined by the following analytical expression $\mathrm{t}_{\mathrm{SL}}=\Delta \mathrm{T} / \mathrm{T}_{\mathrm{R}}\left(\Delta \mathrm{T}=\mathrm{T}_{\mathrm{L}}-\mathrm{T}_{\mathrm{E}}\right)$.

Is obvious that lower $V_{L}$ and $T_{R}$ values have been observed for positions further away from the cooled interface, due to an increasing formation of the solid, which imposes a thermal resistance to the heat extraction by conduction and, as consequence, an increasing profile of $\lambda_{2}$ has been observed with the advance of horizontal solidification. This is clearly seen by the three micrographs $(6,40$ and $90 \mathrm{~mm})$ shown

$$
\lambda_{2}=\frac{L}{(n-1)}
$$

Microindentation in Al-rich primary phase $\left(\mathrm{Al}_{(\alpha)}\right)$

Microindentation in Interdendritic eutectic mixture

in the upper part of the macrograph (Figure 6a) the coarser microstructure from the cooled interface.

Figure 7 shows SEM micrographs with EDS/mapping microanalysis for two longitudinal samples in the assolidified ingot from the cooled interface. Microanalysis has been performed by mapping elements to a linear length through several secondary braches. It is observed, for both cases, that the line intercepts the primary and interdendritic phases. Obviously, this is evidenced higher spectra peaks for the $\mathrm{Si}, \mathrm{Mg}$ and Fe elements within the intedendritic region which have allowed to form the eutectic mixture consisting of $\mathrm{Al}{ }_{\text {( } \alpha \text {-eutectic) }}+\mathrm{Si}+\mathrm{Al}_{8} \mathrm{Mg}_{3} \mathrm{FeSi}_{6}(\pi)+\mathrm{Mg}_{2} \mathrm{Si}(\theta)$, as seen theoretically by Figures 1 and 2 .

In this work, the $\mathrm{HV}$ dependence on the thermal and structural parameters of the Al-7wt.\%Si-0.3wt.\%Mg alloy has been evaluated by measuring of $\mathrm{HV}$ in the phases of the Al-rich $\left(\mathrm{Al}_{\alpha)}\right.$ and interdendritic $\left[\mathrm{Al}{ }_{(\alpha \text {-eutectic })}+\mathrm{Si}+\right.$ $\left.\mathrm{Al}_{8} \mathrm{Mg}_{3} \mathrm{FeSi}_{6}(\pi)+\mathrm{Mg}_{2} \mathrm{Si}(\theta)\right]$ regions. Figure 8 shows the experimental results of $\mathrm{HV}=\mathrm{f}\left(\mathrm{P}, \mathrm{V}_{\mathrm{L}}, \mathrm{T}_{\mathrm{R}}\right.$ and $\left.\lambda_{2}\right)$, where $\mathrm{P}$ is liquidus isotherm position. It is observed that higher $\mathrm{HV}$ values were obtained in the interdendritic regions, in which $\mathrm{Si}+\pi+\theta$ particles of high hardness are present. Vasconcelos et al. ${ }^{48}$, Araújo et al. ${ }^{28}$ and Souza et al. ${ }^{40}$ have found higher HV values for Al-Si multicomponent alloys with addition of $\mathrm{Cu}$ and $\mathrm{Mg}$ and the authors have attributed to the presence of intermetallic phases $\left(\mathrm{Al}_{2} \mathrm{Cu}\right.$ and $\left.\mathrm{Mg}_{2} \mathrm{Si}\right)$ of high hardness in the interdendritic region of the as-solidified samples. In contrast to the procedure adopted in the present study, these authors did not perform HV measurements in the Al-rich and eutectic phases, the HV values reported by them were the means of 20 measurements obtained directly in the casting samples.

Figure 9 presents, for one of the analyzed samples ( $\mathrm{P}=20 \mathrm{~mm}$ ), the effect of Al-rich (dendritic primary phase) and interdendritic (eutectic mixture) phases on the formation of microindentation caused during the application of the load for $\mathrm{HV}$ measurement. It is noted that the HV microindentation is smaller in the region of greater hardness, in which the phases of eutectic composition of higher HV values are 

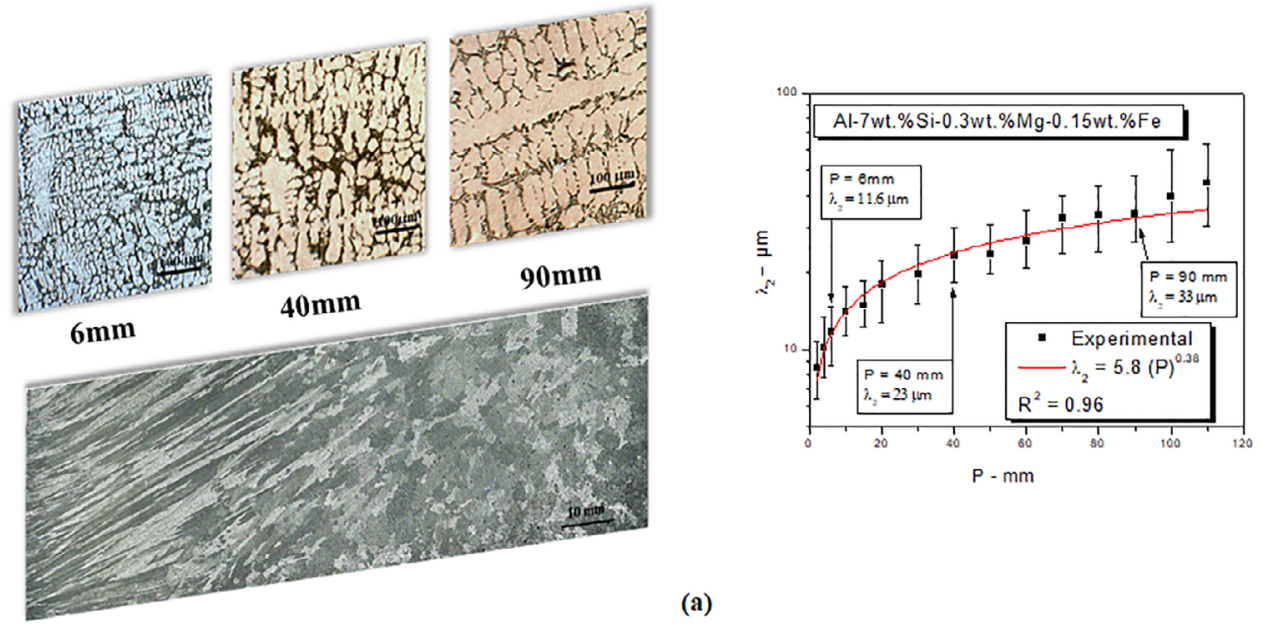

(a)
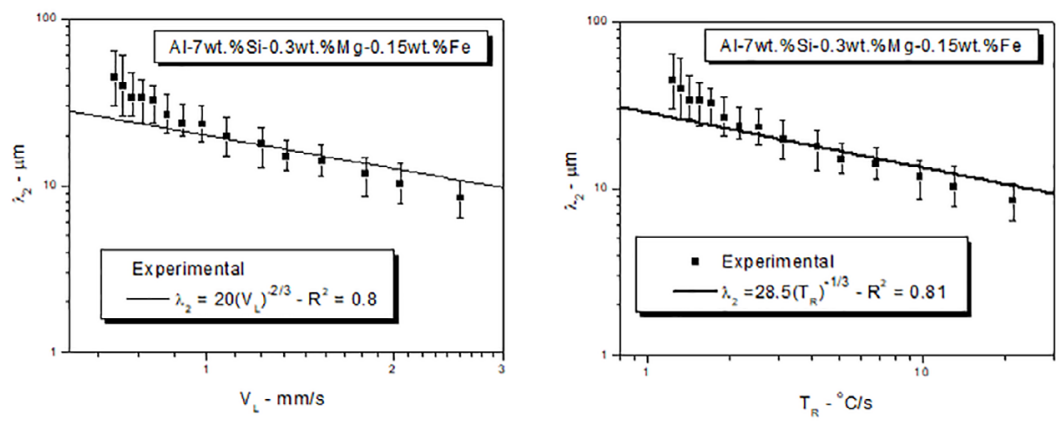

(b)

Figure 6. Microstructural evolution and correlation with the solidification thermal parameters: (a) Typical solidification macroestructure and microstructure and $\lambda_{2}=\mathrm{f}(\mathrm{P}) ;(\mathrm{b}) \lambda_{2}=\mathrm{f}\left(\mathrm{V}_{\mathrm{L}}\right.$ and $\left.\mathrm{T}_{\mathrm{R}}\right)$.
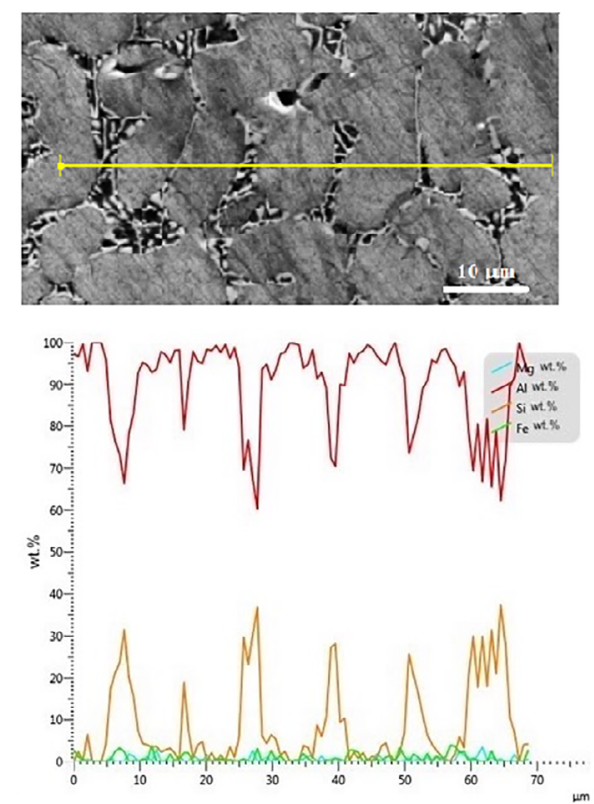

(a)
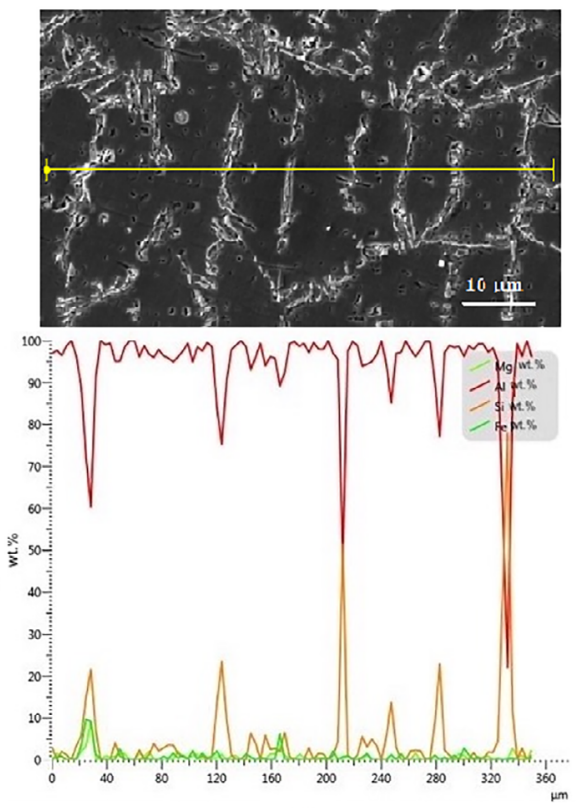

(b)

Figure 7. SEM micrographs with EDS/mapping microanalysis for the following positions in the as-cast ingot: (a) $\mathrm{P}$ $=2 \mathrm{~mm}$ and $(\mathrm{b}) \mathrm{P}=100 \mathrm{~mm}$. 


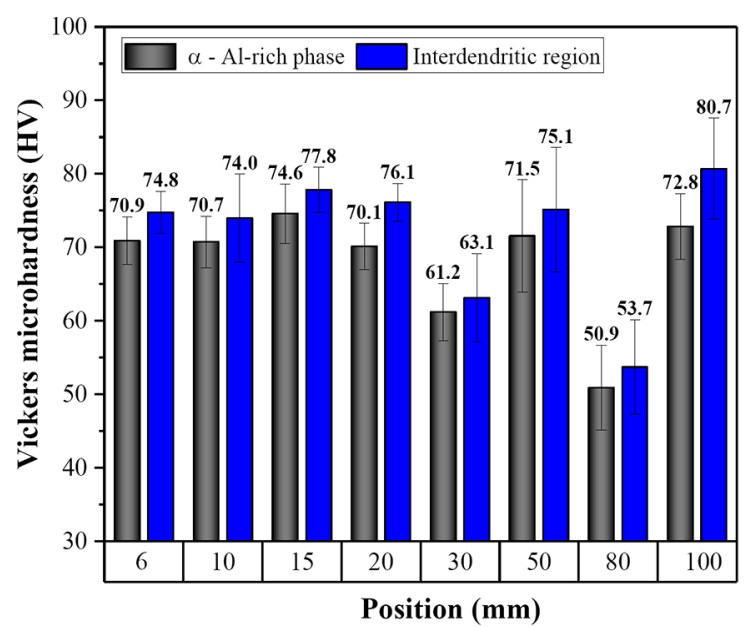

(a)

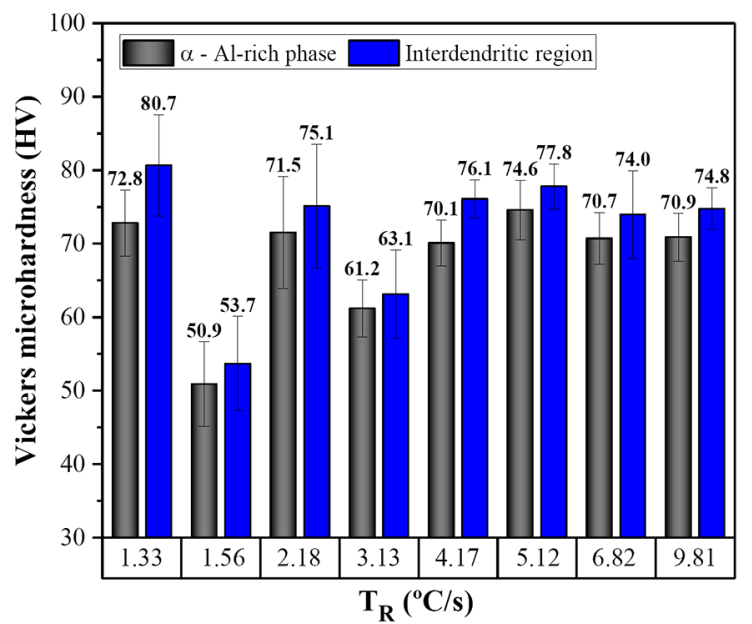

(c)

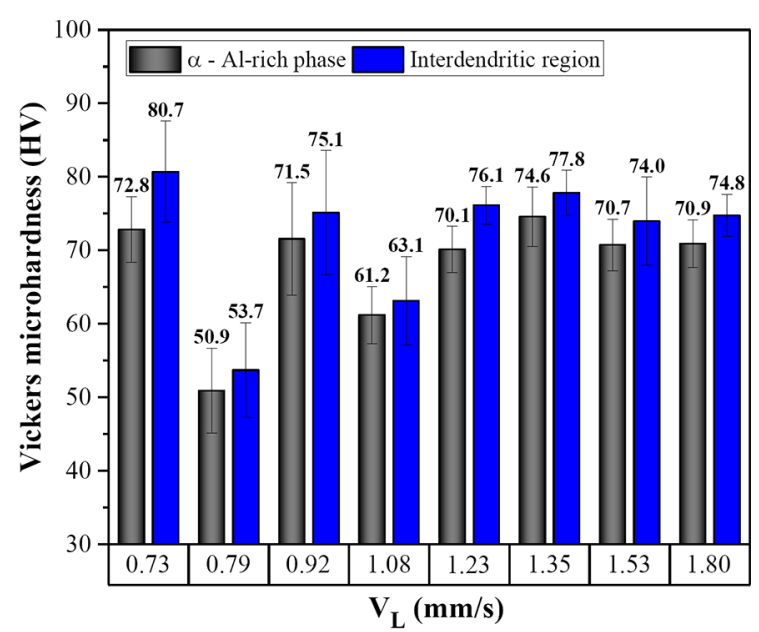

(b)

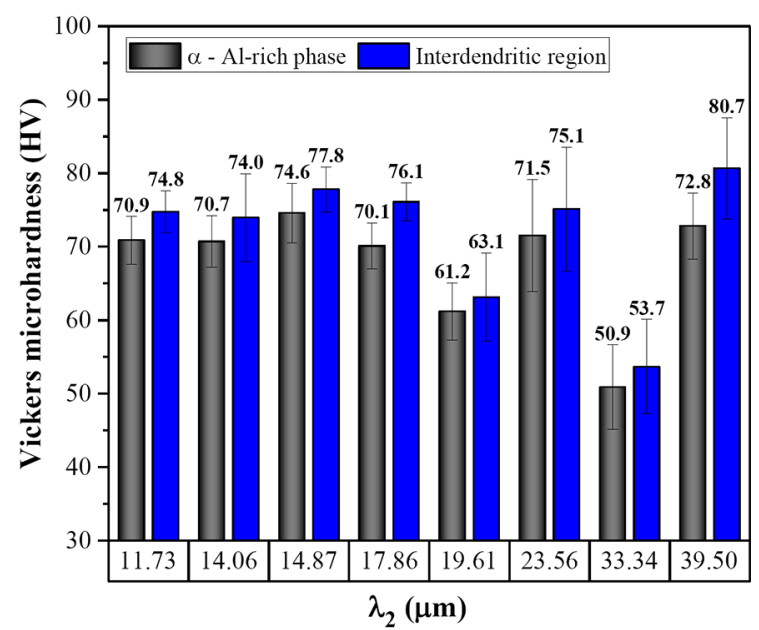

(d)

Figure 8. HV variation with a function of: (a) ingot position - P, (b) growth rate $-V_{L}$, (c) cooling rate $-T_{R}$ and (d) secondary dendritic spacing $\lambda_{2}$.

present. Barros et al. ${ }^{21}$ developed a study with horizontally solidified $\mathrm{Al}-\mathrm{XCu}(\mathrm{X}=3$ and $8 \mathrm{wt} \%)$ alloys, presenting as results a comparison between the impressions of the $\mathrm{HV}$ microindentations observed in the $\mathrm{Al}_{(\alpha)}$ dendritic primary and $\mathrm{Al}_{\text {(a-eutectic) }}+\mathrm{Al}_{2} \mathrm{Cu}$ interdendritic phases, which also showed smaller microindentations in the interdendritic region.

In order to analyze the phases present during the solidification process of the investigated alloy, SEM/EDS mapping and microanalysis of the EDS compositions have been elaborated in the sample positioned at $100 \mathrm{~mm}$ of the refrigerated interface, position of the liquidus isotherm where higher HV values were found, and the results are shown in Figure 10. It is seen in Figure 10a that the L1 and L2 dimensions of the microindentation diagonals in the aluminum-rich region are higher. The mean values obtained [(L1 + L2)/2] were 34.96 and 31.34 in the $\mathrm{Al}_{\alpha}$ and interdendritic $\mathrm{Al}_{\text {(a-eutectic) }}+\mathrm{Si}+\mathrm{Al}_{8} \mathrm{Mg}_{3} \mathrm{FeSi}_{6}(\pi)+\mathrm{Mg}_{2} \mathrm{Si}(\theta)$ regions, respectively, representing an approximate difference of $11 \%$. This percentage difference has also been evidenced between the $\mathrm{HV}$ values (72.8 and 80.7 ) for the same position $(100 \mathrm{~mm})$, as observed in Figure $8 \mathrm{a}$.

It was possible to verify in Figures $8 \mathrm{a}$ and 9 that the maximum $\mathrm{HV}$ value was obtained at position $100 \mathrm{~mm}$, in which, although this position presents the lowest $T_{R}$ and higher $\lambda_{2}$ values (see Figures $8 \mathrm{c}$ and $8 \mathrm{~d}$ ), the Si particles are in larger size, in lamellar form and present high hardness, as can be seen in Figure 11. It is also evidenced by SEM micrographs presented at the top of Figure 11 the influence of higher $T_{R}$ values in the formation of Si particles with fine and fibrous morphology. In a recent paper, Costa et al. ${ }^{26}$ have evaluated the effects of $\mathrm{T}_{\mathrm{R}}$ on the size and morphology of $\mathrm{Si}$ particles in the $\mathrm{Al}-5.5 \mathrm{wt} \% \mathrm{Si}-3 \mathrm{wt} \% \mathrm{Cu}$ alloy, solidified in the upward direction and subjected to a precipitation hardening heat treatment. These authors have observed that for higher $T_{R}$ values the $\mathrm{Si}$ was found in the as-cast microstructure in the 


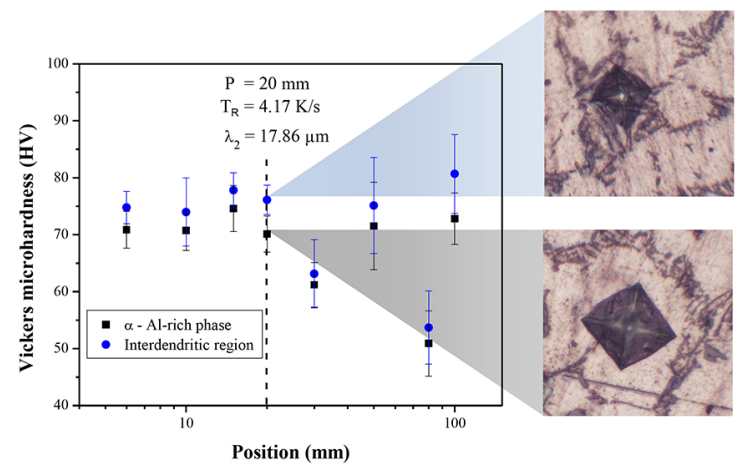

Figure 9. Schematic representation of the effect of the phases on the HV microindentation at position equal to $20 \mathrm{~mm}$ from the refrigerated interface. fibrous form and this has potentiated the its spheroidization after the solution heat treatment.

\section{Conclusions}

The major conclusions can be drawn from the present investigation:

1. SEM / EDS mapping combined with microanalysis of the EDS compositions showed that the as-cast microstructure of the $\mathrm{Al}-7 \mathrm{wt} \%-\mathrm{Si}-0.3 \mathrm{wt} \% \mathrm{Mg}$ $0.15 \mathrm{wt} \% \mathrm{Fe}$ alloy consists of: an aluminum-rich dendritic phase $\left(\mathrm{Al}_{(\alpha)}\right)$ and a eutectic interdendritic

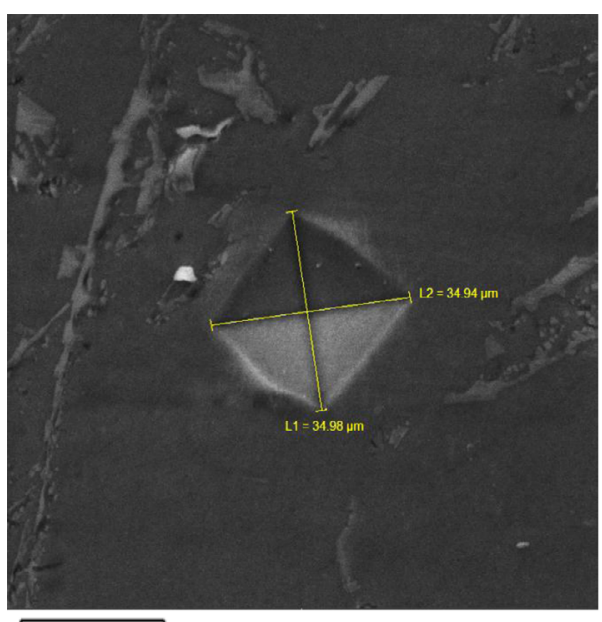

$25 \mu \mathrm{m}$

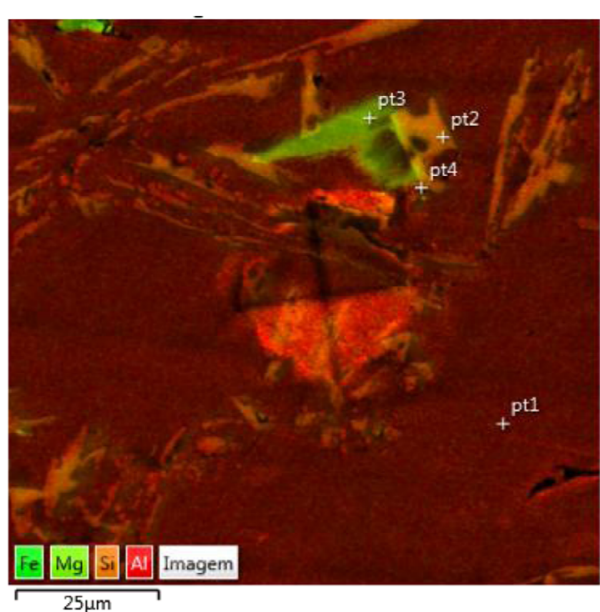

(b)

\section{)}

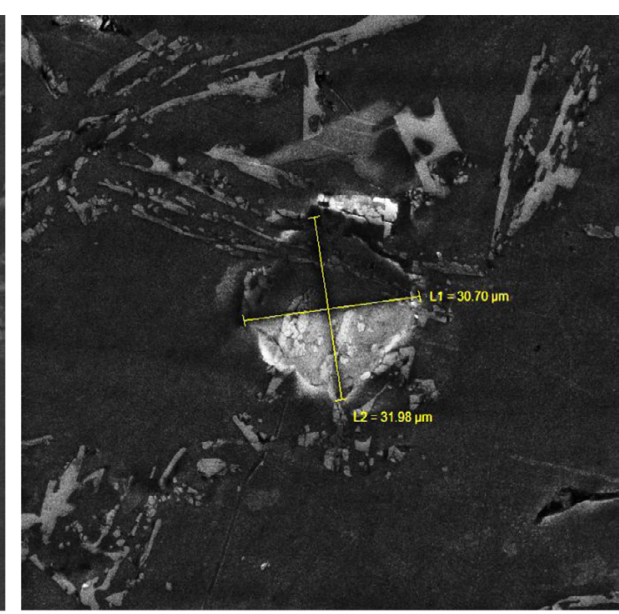

(a)

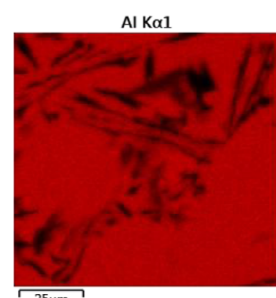

Mg Ka1_2
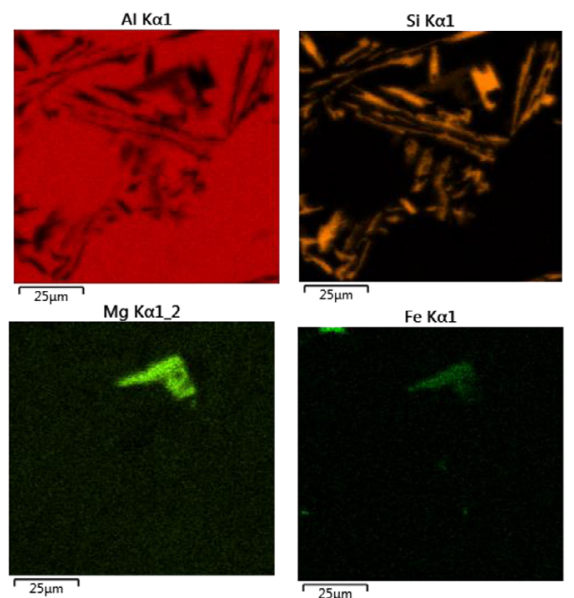

\begin{tabular}{ccccc}
\hline \multicolumn{5}{c}{$\mathbf{P}=\mathbf{1 0 0} \mathbf{~ m m}$} \\
\hline \multirow{2}{*}{ Point } & Al & Si & $\mathbf{M g}$ & $\mathbf{F e}$ \\
\cline { 2 - 5 } & A8.72 & 1.28 & - & - \\
\hline 1 & $98)$ & - \\
\hline 2 & 12.77 & 87.23 & - & - \\
\hline 3 & 56.35 & 22.09 & 13.69 & 7.87 \\
\hline 4 & 66.9 & 31.86 & 0.88 & 0.36 \\
\hline
\end{tabular}

(c)

Figure 10. Representation of microindentation by scanning electron microscopy (SEM) at position equal to $100 \mathrm{~mm}$ : (a) SEM micrograph, (b) elemental mapping, (c) ponctual EDS analysis. 


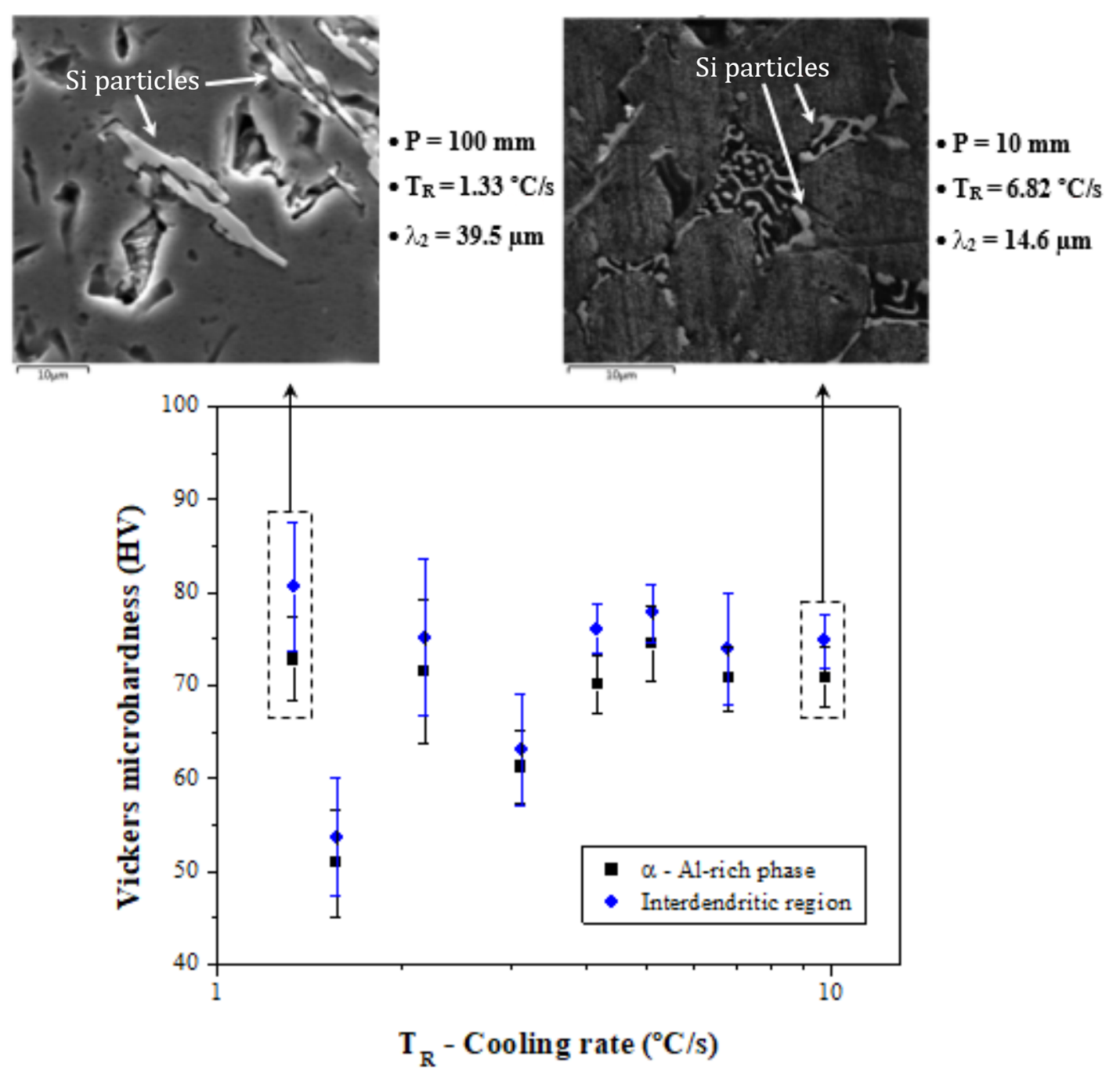

Figure 11. Effect of the cooling rate on the Si morphology and HV values.

mixture composed of the $\mathrm{Al}_{(\alpha-\text { eutectic })}+\mathrm{Si}+\mathrm{Al}_{8} \mathrm{Mg}_{3} \mathrm{FeSi}_{6(\pi)}$ $+\mathrm{Mg}_{2} \mathrm{Si}_{(\theta)}$ phases.

2. The dendritic morphology was the microstructure of the primary phase $\left[\mathrm{Al}_{(\alpha)}\right]$ observed along the length of the ingot of the investigated alloy. It has been quantified by the secondary dendrite arms spacings and the following mathematical expressions have characterized the $\lambda_{2}$ dependence on the $\mathrm{V}_{\mathrm{L}}$ and $\mathrm{T}_{\mathrm{R}}$ values: $\lambda_{2}=20\left(\mathrm{~V}_{\mathrm{L}}\right)^{-2 / 3}$ and $\lambda_{2}=28.5\left(\mathrm{~T}_{\mathrm{R}}\right)^{-1 / 3}$.

3. Obviously, higher HV values were observed in the interdendritic region, where high hardness phases are present. However, this work presents as novelty to the literature, for the investigated alloy and solidified under assumed conditions, experimental values of $\mathrm{HV}$ in the Al-rich and eutectic phases.

4. Finer and fibrous Si particles have been verified in samples located closer to the cooled base of the horizontal solidification device, in which the $T_{R}$ and $\lambda_{2}$ values are higher and smaller, respectively.

5. It was observed that the maximum HV values were found at the position equal to $100 \mathrm{~mm}$ from the cooled interface, where the Si particles in the plate-type morphology of larger sizes and higher harder are present.

\section{Acknowledgments}

The authors acknowledge the financial support provided by IFPA - Federal Institute of Education, Science and Technology of Pará, UFPA - Federal University of Pará, and CNPq - The Brazilian Research Council (grants 302846/2017-4 and 400634/2016-3) and CAPES - Coordination of Superior Level Staff Improvement, Brazil. 


\section{References}

1. Steinbach S, Ratke L. The Influence of Fluid Flow on the Microstructure of Directionally Solidified AlSi-Base Alloys. Metallurgical and Materials Transactions A. 2007;38(7):13881394.

2. Peres MD, Siqueira CA, Garcia A. Macrostructural and microstructural development in Al-Si alloys directionally solidified under unsteady-state conditions. Journal of Alloys and Compounds. 2004;381(1-2):168-181.

3. Carvalho DB, Guimarães EC, Moreira AL, Moutinho DJ, Dias Filho JM, da Rocha OL. Characterization of the Al-3wt.\%Si alloy in unsteady-state horizontal directional solidification. Materials Research. 2013;16(4):874-883.

4. Carvalho DLB, Costa TAPS, Moreira ALS, Silva MAPS, Dias Filho JM, Moutinho DJC, et al. Solidification thermal parameters and dendritic growth during the horizontal directional solidification of Al-7wt.\%Si alloy. REM: Revista Escola Minas. 2014;67(3):265-270.

5. Kaya H, Çadirli E, Gündüz M, Ülgen A. Effect of the temperature gradient, growth rate, and the interflake spacing on the microhardness in the directionally solidified Al-Si eutectic alloy. Journal of Materials Engineering and Performance. 2003;12(5):544-551.

6. Kaya H, Çadirli E, Gündüz M. Dendritic Growth in an Aluminum-Silicon Alloy. Journal of Materials Engineering and Performance. 2007;16(1):12-21.

7. Verma A, Kumar S, Grant PS, O'Reilly KAQ. Influence of cooling rate on the Fe intermetallic formation in an AA6063 Al alloy. Journal of Alloys and Compounds. 2013;555:274-282.

8. Gündüz M, Çadirli E. Directional solidification of aluminiumcopper alloys. Materials Science and Engineering: A. 2002;327(2):167-185.

9. Sá F, Rocha OL, Siqueira CA, Garcia A. The effect of solidification variables on tertiary dendrite arm spacing in unsteady-state directional solidification of $\mathrm{Sn}-\mathrm{Pb}$ and Al-Cu alloys. Materials Science and Engineering: A. 2004;373(1-2):131-138.

10. Dong Y, Zheng RG, Lin XP, Ye J, Sun L. Investigation on the modification behavior of A356 alloy with a Sr-Y composite modifier. Journal of Rare Earths. 2013;31(2):204-208.

11. Kirkwood DH. Simple model for dendritic arm coaserning during solidification. Materials Science and Engineering. 1985;73:L1-L4

12. Trivedi R, Kurz W. Dendritic growth. International Materials Reviews. 1994;39(2):49-74.

13. Okamoto T, Kishitake K. Dendritic structure in unidirectionally solidified aluminum, tin, and zinc base binary alloys. Journal of Crystal Growth. 1975;29(2):137-146.

14. Hunt JD, Lu SZ. Numerical modeling of cellular/dendritic array growth: spacing and structure predictions. Metallurgical and Materials Transactions A. 1996;27(3):611-623.

15. Kurz W, Fisher DJ. Dendrite growth at the limit of stability: tip radius and spacing. Acta Metallurgica. 1981;29(1):11-20.
16. Bouchard D, Kirkaldy JS. Prediction of dendrite arm spacings in unsteady and steady-state heat flow of unidirectionally solidified binary alloys. Metallurgical and Materials Transactions $B$. 1997;28(4):651-663.

17. Rocha OL, Siqueira CA, Garcia A. Heat flow parameters affecting dendrite spacings during unsteady-state solidification of $\mathrm{Sn}-\mathrm{Pb}$ and Al-Cu alloys. Metallurgical and Materials Transactions A. 2003;34(4):995-1006.

18. Kaya H, Böyük U, Çadirli E, Marasli N. Measurements of the microhardness, electrical and thermal properties of the Al-Ni eutectic alloy. Materials \& Design. 2012;34:707-712.

19. Kaya H, Böyük U, Çadirli E, Marasli N. Influence of growth rate on microstructure, microhardness, and electrical resistivity of directionally solidified Al-7wt $\%$ Ni hypo-eutectic alloy. Metals and Materials International. 2013;19(1):39-44.

20. Çadirli E. Effect of solidification parameters on mechanical properties of directionally solidified Al-rich Al-Cu alloys. Metals and Materials International. 2013;19(3):411-422.

21. Barros AS, Magno IL, Souza FA, Moreira AL, Silva MA, Rocha OL. Measurements of microhardness during transient horizontal directional solidification of Al-rich Al-Cu alloys: Effect of thermal parameters, primary dendrite arm spacing and $\mathrm{Al} 2 \mathrm{Cu}$ intermetallic phase. Metals and Materials International. 2015;21(3):429-439.

22. Rappaz M, Boettinger WJ. On dendritic solidification of multicomponent alloys with unequal liquid diffusion coefficients. Acta Materialia. 1999;47(11):3205-3219.

23. Brito C, Costa TA, Vida TA, Bertelli F, Cheung N, Spinelli, JE, et al. Characterization of Dendritic Microstructure, Intermetallic Phases, and Hardness of Directionally Solidified Al-Mg and Al-Mg-Si Alloys. Metallurgical and Materials Transactions A. 2015;46(8):3342-3355.

24. Chen R, Shi YF, Xu QY, Liu BC. Effect of cooling rate on solidification parameters and microstructure of Al-7Si-0.3Mg$0.15 \mathrm{Fe}$ alloy. Transactions of Nonferrous Metals Society of China. 2014;24(6):1645-1652.

25. Costa TA, Moreira AL, Moutinho DJ, Dias M, Ferreira IL, Spinelli $\mathrm{JE}$, et al. Growth direction and $\mathrm{Si}$ alloying affecting directionally solidified structures of $\mathrm{Al}-\mathrm{Cu}-\mathrm{Si}$ alloys. Materials Science and Technology. 2015;31(9):1103-1112.

26. Costa TA, Dias M, Gomes LG, Rocha OL, Garcia A. Effect of solution time in $\mathrm{T} 6$ heat treatment on microstructure and hardness of a directionally solidified Al-Si-Cu alloy. Journal of Alloys and Compounds. 2016;683:485-494.

27. Gomes LG, Moutinho DJ, Ferreira IL, Rocha OL, Garcia A. The Growth of Secondary Dendritic Arms in Directionally Solidified Al-Si-Cu Alloys: A Comparative Study with Binary Al-Si Alloys. Applied Mechanics and Materials. 2015;719-720:102-105.

28. Araújo EC, Barros AS, Kikuchi RH, SilvaAP, Gonçalves FA, Moreira AL, Rocha OL. The Role of Si and Cu Alloying Elements on the Dendritic Growth and Microhardness in Horizontally Solidified Binary and Multicomponent Aluminum-BasedAlloys. Metallurgical and Materials Transactions A. 2017;48(3):1163-1175.

29. Mikolajczak P. Microstructural Evolution in AlMgSi Alloys during Solidification under Electromagnetic Stirring. Metals. 2017;7(3):89. 
30. Chen R, Xu Q, Guo H, Xia Z, Wu Q, Liu B. Correlation of solidification microstructure refining scale, $\mathrm{Mg}$ composition and heat treatment conditions with mechanical properties in $\mathrm{Al}-7 \mathrm{Si}-\mathrm{Mg}$ cast aluminum alloys. Materials Science and Engineering: A. 2017;685:391-402.

31. Çadirli E, Aker A, Kaygisiz Y, Sahin M. Influences of Growth Velocity and Fe Content on Microstructure, Microhardness and Tensile Properties of Directionally Solidified Al-1.9Mn-xFe Ternary Alloys. Materials Research. 2017;20(3):801-813.

32. Samuel AM, Doty HW, Valtierra S, Samuel FH. Relationship between tensile and impact properties in $\mathrm{Al}-\mathrm{Si}-\mathrm{Cu}-\mathrm{Mg}$ cast alloys and their fracture mechanisms. Materials \& Design. 2014;53:938-946.

33. CruzKS, Spinelli JE, Ferreira IL, Cheung N, GarciaA. Microstructural development in Al-Sn alloys directionally solidified under transient heat flow conditions. Materials Chemistry and Physics. 2008;109(1):8798.

34. Goulart PR, Spinelli JE, Cheung N, Garcia A. The effects of cell spacing and distribution of intermetallic fibers on the mechanical properties of hypoeutectic Al-Fe alloys. Materials Chemistry and Physics. 2010;119(1-2):272-278.

35. Verissimo NC, Brito C, Afonso CR, Spinelli JE, Cheung N, Garcia A. Microstructure characterization of a directionally solidified $\mathrm{Mg}$ 12wt.\%Zn alloy: Equiaxed dendrites, eutectic mixture and type/ morphology of intermetallics. Materials Chemistry and Physics. 2018;204:105-131.

36. Dias M, Brito C, Bertelli F, Garcia A. Cellular growth of single-phase $\mathrm{Zn}-\mathrm{Ag}$ alloys unidirectionally solidified. Materials Chemistry and Physics. 2014;143(3):895-899.

37. Silva JN, Moutinho DJ, Moreira AL, Ferreira IL, Rocha OL. Determination of heat transfer coefficients at metal-mold interface during horizontal unsteady-state directional solidification of $\mathrm{Sn}-\mathrm{Pb}$ alloys. Materials Chemistry and Physics. 2011;130(1-2):179-185.

38. Carvalho D, Rodrigues J, Soares D, Aviz J, Barros A, Silva M, et al. Microindentation Hardness-Secondary Dendritic Spacings Correlation with Casting Thermal Parameters in an Al-9wt.\%Si Alloy. Materials Science. 2018;24(1):18-23.

39. Silva CAP, Leal LRM, Guimarães EC, Júnior PM, Moreira AL, Rocha OL, et al. Influence of Thermal Parameters, Microstructure, and Morphology of Si on Machinability of an Al-7.0wt.\% Si Alloy Directionally Solidified. Advances in Materials Science and Engineering. 2018;2018:9512957.
40. Souza F, Lima J, Rizziolli C, Magno I, Barros A, Moreira A, et al. Microstructure and microhardness in horizontally solidified Al-7Si-0.15Fe- $(3 \mathrm{Cu} ; 0.3 \mathrm{Mg})$ alloys. Materials Science and Technology. 2018;34(10):1252-1264.

41. Çardili E. Effect of solidification parameters on mechanical properties of directionally solidified Al-Rich Al-Cu alloys. Metals and Materials International. 2013;19(3):411-422.

42. Kaya H, Çadirli E, Böyük U, Marasli N. Variation of microindentation hardness with solidification and microstructure parameters in the Al based alloys. Applied Surface Science. 2008;255(5 Pt 2):3071-3078.

43. Acer E, Çadirli E, Erol H, Gündüz M. Effect of Growth Rate on the Microstructure and Microhardness in a Directionally Solidified Al-Zn-Mg Alloy. Metallurgical and Materials Transactions A. 2016;47(6):3040-3051.

44. Silva BL, Cheung N, Garcia A, Spinelli JE. Sn- $0.7 \mathrm{wt} \% \mathrm{Cu}-(\mathrm{xNi})$ alloys: Microstructure-mechanical properties correlations with solder/substrate interfacial heat transfer coefficient. Journal of Alloys and Compounds. 2015;632:274-285.

45. Canté MV, Brito C, Spinelli JE, Garcia A. Interrelation of cell spacing, intermetallic compounds and hardness on a directionally solidified Al-1.0Fe-1.0Ni alloy. Materials \& Design. 2013;51:342-346.

46. Bertelli F, Cheung N, Ferreira IL, Garcia A. Evaluation of thermophysical properties of Al-Sn-Si alloys based on computational thermodynamics and validation by numerical and experimental simulation of solidification. The Journal of Chemical Thermodynamics. 2016;98:9-20.

47. Vasconcelos AJ, Silva CVA, Moreira ALS, Silva MAPS, Rocha OFL. Influence of thermal parameters on the dendritic arm spacing and the microhardness of Al-5.5wt.\%Sn alloy directionally solidified. REM: Revista Escola de Minas. 2014;67(2):173-179.

48. Vasconcelos AJ, Kikuchi RH, Barros AS, Costa TA, Dias M, Moreira AL, et al. Interconnection between microstructure and microhardness of directionally, solidified binary A16wt.\% $\%$ und multicomponent Al-6wt.\%Cu-8wt.\%Si alloys. Anais da Academia Brasileira de Ciências. 2016;88(2):10991111. 